А.М. Нагорна ${ }^{1}$, Д.В. Варивончик ${ }^{2}$, Л.В. Харчук ${ }^{3}$, Н.В. Медведовська ${ }^{4}$, І.Г. Кононова В.А. Гвоздецький

\title{
ОРГАНІЗАЦІЯ РОЗСЛІДУВАННЯ ТА МЕДИКО-СТАТИСТИЧНІ ЗАКОНОМІРНОСТІ ГОСТРОГО ПРОФЕСІЙНОГО ЗАХВОРЮВАННЯ COVID-19 У ПРАЦІВНИКІВ ГАЛУЗІ ОХОРОНИ ЗДОРОВ'Я УКРАЇНИ (ПЕРШИЙ РІК ПАНДЕМІї: 2020-2021)
}

${ }^{1}$ Національна академія медичних наук України, ${ }^{2}$ Національний університет охорони здоров'я України імені П.Л. Шупика, ${ }^{3}$ Державна служба України з питань праці, ${ }^{4}$ Національна академія медичних наук України, ${ }^{5}$ ДУ «Інститут епідеміології та інфеекційних хвороб імені Л.В. Громашевського НАМН України», ${ }^{6}$ ДУ «Інститут медицини праці імені Ю.І. Кундієва НАМН України»

У 2020 р. проблема зараження коронавірусом людини (2019-nCoV/SARS-CoV-2) стала актуальною у всьому світі. 11.03.2020 р. ВООЗ оголосила пандемію SARS-CoV-2. За один рік пандемії у світі (станом на 12.03.2021 р.) зареєстровано 120,1 млн випадків зараження SARS-CoV-2, з яких внаслідок COVID-19 померли 2,7 млн осіб. В Україні зареєстровано - 1,451 млн інфрікованих SARS-CoV-2 (в т.ч. 68,3 тис. працівників галузі охорони здоров'я (ГОЗ)); з яких внаслідок COVID-19 померли 28,1 тис. осіб (в т.ч. працівників ГОЗ - 612 осіб). На сьогодні однією з найвагоміших науково-практичних проблем залишається оцінка ризиків і профрілактика цієї гострої профресійної патології.

матеріали і методи. Використані офічійні статистичні дані МОЗ України щодо нормативного регулювання епідемічного розслідування COVID-19, організації розслідування COVID-19 у сфрері охорони здоров'я, у сорері охорони праці, обліку випадків захворювання на COVID-19. Отримані та проаналізовані статистичні дані захворюваності на COVID-19 (за інфрормацією територіальних підрозділів Фонду сочіального страхування України, Державної служби України з питань праці) за 2020 р. - березень 2021 р. Використовувались загальноприйняті статистичні методи дослідження для характеристики даних, отриманих для суцільної вибірки в Україні.

Результати досліджень та їх обговорення. Проаналізовані нормативно-правові акти процедури розслідування випадків гострого профресійного захворювання на COVID-19, а саме Наказ МОз України від 25.02.2020 № 521 «Про внесення зміни до Переліку особливо небезпечних, небезпечних інфекційних та паразитарних хвороб людини і носійства збудників цих хвороб, Інструкція № 374 «Про застосування переліку профресійних захворювань», затвердженої спільним наказом МО3, Національної Академії медичних наук України, Мінпраці від 29.12.2000 р. № 374/68/33», Наказ мОЗ України від 15.07.2020 № 1604 щодо Переліку посад медичних та інших працівників, що безпосередньо зайняті у ліквідації епідемії та здійсненні заходів із запобігання поширенню гострої респіраторної хвороби COVID-19, спричиненої коронавірусом SARS-CoV-2, та лікування пацієнтів із випадками гострої респіраторної хвороби COVID-19, спричиненої коронавірусом SARS-CoV-2», Постанова КМУ від 13.05.2020 № 394 розділ V Переліку профресійних захворювань, затвердженого постановою КМУ від 08.11.2000 № 1662, доповнено гострою респіраторною хворобою COVID-19, спричиненою коронавірусом SARS-CoV-2, яка стосується тільки роботи «медичних та інших працівників, що безпосередньо зайняті у ліквідації епідемії та здійсненні заходів із запобігання поширенню гострої респіраторної хвороби COVID-19, спричиненої коронавірусом SARS-CoV-2, та лікування пацієнтів із випадками гострої респіраторної хвороби COVID-19, спричиненої коронавірусом SARS-CoV-2». Визначені медико-статистичні закономірності інфрікування SARS-CoV-2 ma захворювання на COVID-19 працівників галузі охорони здоров'я. Кількість повідомлень про випадки інфрікування SARS-CoV-2 на робочому місці (підозра на гостре профресійне захворювання), що надійшли до Держпраці України (12.03.2021р.), становила - 43130 працівників, 
в т.ч. випадків смертей від COVID-19 - 522. Загалом повнота надходження повідомлень про гостре профресійне захворювання становила (відносно зареєстрованих випадків інфікування ПОЗ): для інфрікування SARS-CoV-2/захворювання на COVID-19 - 63,5 (4,8219,3) \%; випадків смерті від COVID-19 - 85,6 (36,4$450,0) \%$. Коливання рівнів захворюваності на COVID-19 значно відрізняються по областях, причини потребують ретельнішого аналізу, вони багатопланові, але виявлені закономірності можуть слугувати певною основою для ухвалення управлінських рішень щодо обліку, реєстрації, профрілактики і лікування цієї патолоziï.

Висновки. Кількість хворих на гостре професійне захворювання COVID-19 постійно збільшується, має хвилеподібний характер, відповідно до загального перебігу епідемії в популяції населення України. Кумулятивний ризик інфікування SARS-CoV-2 працівниками галузі охорони здоров'я вищий в 2,5 рази, ніж серед загального населення, а смерті від COVID-19 - в 1,1 разу.

Домінуючі причини інфрікування SARS-CoV-2 прачівників галузі охорони здоров'я: надання медичної допомоги хворим на COVID-19 зі здійсненням інтервенційних процедур (46,3%); наявні організаційні недоліки в забезпечені інфрекційного контролю в 303 (33,7 \%); психофрізіологічні причини, які обумовлені роботою працівників в екстремальних умовах надання стаціонарної допомоги хворим на COVID-19 («червона зона») (14,0 \%); технічні (4,5\%); техногенні, природні, екологічні та соціальні (1,4\%).

Нормативне регулювання встановлення гострого профресійного захворювання на COVID-19 регламентовано тільки для працівників галузі охорони здоров'я $і$ потребує розповсюдження його й на інші види економічної діяльності в Україні (працівники освіти, соціальної допомоги тощо).

Є суттєві організаційні та ресурсні (кадрові) недоліки: з надання повідомлень до Держпраці України щодо підозри гострого професійного захворювання на COVID-19 та смерті від нього; щодо об'єктивної статистичної реєстрації випадків захворювання працівників галузі охорони здоров'я на COVID-19; щодо своєчасного та повного розслідування зв'язку захворювання (смерті) з умовами праці тощо.

Подальші дослідження будуть спрямовані на удосконалення системи оцінки ризиків та убезпечення роботи працівників галузі охорони здоров'я, в умовах епідемії SARS-CoV-2/COVID-19 в Україні.

Ключові слова: гостре професійне захворювання, COVID-19, галузь охорони здоров'я, причини інфрікування SARS-CoV-2.
Проблема зараження коронавірусом людини (2019nCoVISARS-CoV-2) стала актуальною у всьому світі, коли у 31.12.2019 р. в м. Ухань (КНР) були зафріксовані перші 27 випадків пневмонії невідомого походження, про що було повідомлено ВООЗ [1].

22.01.2020 р. відбулось засідання Міжнародного комітету ВООЗ з питань надзвичайних ситуацій у сфрері охорони здоров'я, внаслідок якого експертами не було оголошено надзвичайну ситуацію в галузі міжнародної охорони здоров'я. 30.01.2020 р. відбулось чергове засідання Комітету, після якого Генеральний директор ВООЗ Тедрос Адан Гебрейєсус оголосив надзвичайну ситуацією в галузі міжнародної охорони здоров'я, спричинену спалахом нової коронавірусної інфекції (2019$\mathrm{nCoV})$. ВООЗ запропонувала ввести до Міжнародних медико-санітарних правил (ММСП) (2005р.) попередню назву хвороби - гостра респіраторна хвороба, що спри чинена коронавірусом (2019-nCoV) [2].

11.02.2020 р. Міжнародний комітет з таксономії вірусів ухвалив офріційну назву збудника - SARS-CoV-2 (Severe Acute Respiratory Syndrome Coronavirus 2 I тяжкий гострий респіраторний синдром коронавірус 2) та назву захворювання, що він спричиняє - COVID-19 (COrona VIrus Disease) [3].

11.03.2020 р. ВОО3 оголосила пандемію SARSCoV-2 [4]. А відповідно до Постанови Кабінету Міністрів України від 11 березня 2020 р. № 211 «Про запобігання поширенню на території України гострої респіраторної хвороби COVID-19, спричиненої коронавірусом SARSCoV-2» на території України введено карантин, який діє і до теперішнього часу (березень 2021 р.).

20.04.2020 р. ВООЗ терміново додала зміни до Міжнародної статистичної класифрікації хвороб Десятого перегляду (MKX-10) для медико-статистичного обліку та реєстрації випадків COVID-19 у розділ «Коди для екстреного використання»: U07.1 (COVID-19, вірус ідентифріковано); U07.2 (COVID-19, вірус не ідентифріковано); U08 (раніше перенесений COVID-19); U09 (стан після перенесеного COVID-19); U11 (мультисистемний запальний синдром, пов'язаний із COVID-19) та інші [5, 6].

За один рік пандемії у світі (станом на 12.03.2021р.) зареєстровано 120,1 млн випадків зараження SARSCoV-2, з яких внаслідок COVID-19 померли 2,7 млн осіб [7]. В Україні (без тимчасово окупованих територій) зареєстровано інфрікованих SARS-CoV-2 - 1,451 млн осіб (в т.ч. 68,3 тис. працівників ГО3); з яких внаслідок COVID-19 померли 28,1 тис. осіб (в т.ч. працівників ГОЗ - 612 осіб) [8].

Останнім часом з'явились публікації, що висвітлюють різні наукові та практичні аспекти професійного інфрікування SARS-CoV-2/COVID-19 [9, 10], однак проблема оцінки ризиків і профрілактики цієї гострої профресійної 
патології залишається однією $з$ найвагоміших науковопрактичних проблем сьогодення, що визначило актуальність цього дослідження.

Мета роботи - удосконалити організацію розслідування та медико-статистичний моніторинг за захворюваннями на гостре професійне захворювання COVID-19 серед працівників галузі охорони здоров'я в України.

\section{Матеріали і методи}

Використані офріційні статистичні дані МОЗ України щодо нормативного регулювання епідемічного розслідування COVID-19, організації розслідування COVID-19 у сфрері охорони здоров'я, у сфері охорони праці, обліку випадків захворювання на COVID-19.

Отримані та проаналізовані статистичні дані щодо захворюваності на COVID-19 (за інформацією територіальних підрозділів Фонду соціального страхування України, Держпраці України) за період березень 2020 р. - березень 2021 p.

Використовувалися загальноприйняті статистичні методи дослідження для характеристики даних, отриманих при суцільній вибірці в Україні.

\section{Результати досліджень та їх обговорення}

Процедура розслідування випадків гострого профресійного захворювання на COVID-19. Відповідно до наказу МОЗ України від 25.02.2020 № 521 «Про внесення змін до Переліку особливо небезпечних, небезпечних інфекційних та паразитарних хвороб людини і носійства збудників цих хвороб, а також згідно з Інструкцією № 374 «Про застосування переліку профресійних захворювань», затвердженої спільним наказом МО3, Національної Академії медичних наук України, Мінпраці від 29.12.2000 р. № 374/68/33» гостра респіраторна хвороба COVID-19, спричинена коронавірусом SARSCoV-2, визнана особливо небезпечною хворобою. Згідно 3 цими документами, відповідно до додатку 3 до Гігієнічної класифрікації праці за показниками шкідливості та небезпеки фракторів виробничого середовища, важкості та напруженості трудового процесу, затвердженої наказом МО3 України від 08.04.2014 № 248, умови праці медичних працівників за біологічним фактором належать до 4 класу небезпеки.

Перелік посад медичних та інших працівників, що безпосередньо зайняті у ліквідації епідемії та здійсненні заходів із запобігання поширенню гострої респіраторної хвороби COVID-19, спричиненої коронавірусом SARS-CoV-2, та лікування пацієнтів із випадками гострої респіраторної хвороби COVID-19, спричиненої коронавірусом SARS-CoV-2», затверджено наказом Міністерства охорони здоров'я України від 15.07.2020 № 1604. Постановою КМУ від 13.05.2020 № 394, розділ V Пере- ліку професійних захворювань, затвердженого постановою КМУ від 08.11.2000 № 1662, доповнено гострою респіраторною хворобою COVID-19, спричиненою коронавірусом SARS-CoV-2, яка стосується тільки роботи «медичних та інших працівників, що безпосередньо зайняті у ліквідації епідемії та здійсненні заходів із запобігання поширенню гострої респіраторної хвороби COVID-19, спричиненої коронавірусом SARS-CoV-2, та лікування пацієнтів із випадками гострої респіраторної хвороби COVID-19, спричиненої коронавірусом SARSCoV-2».

Випадки інфікування SARS-CoV-2 можуть бути професійним захворюванням для таких категорій працівників:

- медичні та інші працівники, що виконують професійні обов'язки в умовах підвищеного ризику зараження збудниками інфрекційних хвороб;

- працівники, які надають медичну допомогу хворим на інфекційні захворювання;

- працівники, які проводять роботу з живими збудниками та в осередках інфекційних хвороб, а також здійснюють дезінфекційні заходи тощо.

У період карантину загрозу інфрікування SARS-CoV-2 мають як працівники закладів охорони здоров'я, які безпосередньо контактують із зараженими пацієнтами, їх біологічними рідинами, так і працівники інших установ, організацій та підприємств, які можуть мати контакт із носіями або хворими в інкубаційному періоді. Під час карантинних заходів такого ризику зазнають насамперед працівники транспорту (громадський транспорт, залізничний, повітряний, водний тощо), аптек, торговельної мережі, що реалізує харчові продукти, працівники АЗС, а також працівники МBC, прикордонники та інші.

Отже, лабораторно підтверджені випадки інфрікування SARS-CoV-2 медичних та інших працівників, які пов'язані з виконанням професійних обов'язків в умовах підвищеного ризику зараження (надання медичної допомоги хворим на інфекційні хвороби, роботи з живими збудниками та в осередках інфекційних хвороб, дезінфекційні заходи тощо), розслідуються як випадки гострого професійного захворювання відповідно до вимог Порядку.

У разі встановлення лабораторно підтвердженого (ПЛР) випадку інфрікування SARS-CoV-2 медичного працівника заклад охорони здоров'я, відповідно до пункту 6 Порядку, зобов'язаний невідкладно передати з використанням засобів зв'язку (факс, телефонограма, електронна пошта) та протягом доби на паперовому носії екстрене повідомлення про звернення потерпілого з посиланням на нещасний випадок та/або гостре професійне захворювання (отруєння) на виробництві (у разі можливості з висновком про ступінь тяжкості травм) за фрормою згідно з додатком 1 до Порядку: 
- підприємству (установі, організації), де працює потерпілий або на якому він виконував роботу;

- територіальному органу Держпраці за місцем настання нещасного випадку та/або гострого профресійного захворювання (отруєння);

- робочому органу виконавчої дирекції Фонду соціального страхування за місцем настання нещасного випадку.

У разі отримання інфрормації про нещасний випадок та/або гостре професійне захворювання (отруєння), а саме, інфікування на COVID-19 медичного працівника, від безпосереднього керівника робіт, повідомлення від закладу охорони здоров'я, заяви потерпілого, членів його сім'ї чи уповноваженої ним особи тощо роботодавець зобов'язаний протягом двох годин повідомити вищезазначеним підприємствам (установам, організаціям), з використанням засобів зв'язку та не пізніше наступного робочого дня надати на паперовому носії повідомлення згідно з додатком 2 до Порядку (пункт 8 Порядку).

Якщо нещасний випадок та/або гостре професійне захворювання (отруєння) підлягають спеціальному розслідуванню відповідно до пункту 10 цього Порядку, повідомлення про нещасний випадок додатково надсилається:

- місцевій держадміністрації або органу місцевого самоврядування (у разі відсутності уповноваженого органу чи наглядової ради підприємства);

- органу галузевої профспілки вищого рівня, а у разі його відсутності - територіальному профоб'єднанню;

- органу поліції (у разі настання нещасного випадку та/або гострого профресійного захворювання (отруєння), що призвели до тяжких (у тому числі з можливою інвалідністю потерпілого) чи смертельних наслідків, смерті працівника під час виконання ним трудових (посадових) обов'язків).

На підприємстві (в установі, організації) створюється комісія з розслідування нещасних випадків та/або гострих професійних захворювань (отруєнь), що не підлягають спеціальному розслідуванню.

Комісія утворюється наказом роботодавця не пізніше наступного робочого дня після отримання інфрормації про нещасний випадок та/або гостре професійне захворювання (отруєння) від безпосереднього керівника робіт, повідомлення від закладу охорони здоров'я, заяви потерпілого, членів його сім'ї чи уповноваженої ним особи (пункт 12 Порядку).

Держпраці та/або її територіальним органом утворюється комісія із спеціального розслідування.

Комісія (спеціальна комісія) зобов'язана, зокрема, за результатами розслідування гострого професійного захворювання (отруєння), пов'язаного з виробництвом, крім Акту за фрормою Н-1, скласти картку обліку професійного захворювання (отруєння) за фрормою П-5 (далі - картка за орормою П-5) згідно з додатком 22 до Порядку, передати не пізніше наступного робочого дня після підписання актів за фрормою Н-1 матеріали розслідування та примірники таких актів керівнику підприємства (установи, організації) або органу, що утворив комісію (спеціальну комісію), для їх розгляду та затвердження (пункт 33 Порядку).

Протягом трьох робочих днів після фрормування матеріалів розслідування, роботодавець повинен надіслати їх адресатам, зазначеним в пункті 47 Порядку.

Акт за фрормою $\mathrm{H}-1$ надається роботодавцем потерпілому, членам його сім'ї чи уповноваженій ними особі.

06 січня 2021 р. спрощено процедуру розслідування випадків смерті медичних працівників внаслідок інфікування гострою респіраторною хворобою COVID-19, спричиненою коронавірусом SARS-CoV-2.

Постановою Кабінету Міністрів України від 05.01.2021 № 1 «Деякі питання розслідування випадків смерті окремих категорій медичних працівників», що набрала чинності 06.01.2021, зокрема внесені зміни до Порядку розслідування та обліку нещасних випадків, професійних захворювань та аварій на виробництві, затвердженого постановою Кабінету Міністрів України від 17.04.2019 № 337 .

Зазначеними змінами визначено процедуру розслідування випадків смерті медичних працівників державних і комунальних закладів охорони здоров'я, що надають первинну, екстрену, а також в стаціонарних умовах вторинну (спеціалізовану) і третинну (високоспеціалізовану) медичну допомогу пацієнтам з гострою респіраторною хворобою COVID-19, спричиненою коронавірусом SARS-CoV-2.

Абзацом другим пункту 1411 Порядку встановлено, що перелік державних і комунальних закладів охорони здоров'я, що надають первинну, екстрену, а також в стаціонарних умовах вторинну (спеціалізовану) і третинну (високоспеціалізовану) медичну допомогу пацієнтам 3 гострою респіраторною хворобою COVID-19, спричиненою коронавірусом SARS-CoV-2, а також медичних працівників таких закладів визначається керівником робіт з ліквідації наслідків надзвичайної ситуації медикобіологічного характеру державного рівня, пов'язаної із поширенням COVID-19 Розпорядженням керівника робіт з ліквідації наслідків надзвичайної ситуації медико-біологічного характеру державного рівня, пов'язаної із поширенням коронавірусної хвороби COVID-19 від 14.01.2021 № 1, затверджено Перелік закладів охорони здоров'я. 


\section{Медико-статистичні закономірності інфріку- вання SARS-CoV-2 та захворювання на COVID-19 працівників галузі охорони здоров'я}

За даними Національної служби здоров'я України (HСЗУ), станом на 12.03.2021 р. в Україні SARS-CoV-2 інфрікувалось понад 1,471 млн осіб (в т. ч. 67,5 тис. працівників ГО3; 4,8 \% від усіх інфікованих). Найбільша кумулятивна кількість іноікованих працівників ГОЗ зареєстрована в м. Києві (9,3 \% до всіх), Київській (7,6 \%), Запорізькій (6,2 \%), Хмельницькій (5,5\%), Черкаській (5,3 \%), Львівській (5,1 \%) областях (табл. 1).

Абсолютна кількість смертей від COVID-19 - 28,6 тис. осіб (летальність - 1,9 \%), в т. ч. працівників ГОЗ 610 осіб (летальність 0,9%). Найбільша кумулятивна кількість померлих працівників ГОЗ зареєстрована в Львівській (8,2 \%), Київській (8,0 \%), Харківській (8,0 \%) областях, м. Києві (6,2 \%), Дніпропетровській (6,1 \%), Донецькій (5,6 \%), Івано-Франківській (5,6 \%), Одеській (5,4 \%) та Чернівецькій (5,4 \%) областях (табл. 1).

Ми визначили, що в когорті працівників ГОЗ України відносний кумулятивні ризик (RR) становив: інфікування SARS-CoV-2 - 2,49 (95 \% Cl $95 \%$ : 2,47 - 2,51, p<0,0001); смерті від COVID-19 - 1,12 (Cl 95 \% Cl: 1,03 - 1,20; $\mathrm{p}<0,007)$.

Кількість повідомлень про випадки інфікування SARS-CoV-2 на робочому місці (підозра на гостре професійне захворювання), що надійшли до Держпраці України (12.03.2021р.), становила 43130 працівників, в т.ч. випадки смертей від COVID-19 - 522. Загалом повнота надходження повідомлень про гостре професійне захворювання становила (відносно зареєстрованих випадків інфрікування ПОЗ): для інфрікування SARSCoV-2/захворювання на COVID-19 - 63,5 (4,8 - 219,3) \%; випадків смерті від COVID-19 - 85,6 (36,4 - 450,0) \% (табл. 1).

Необхідно зазначити, що відбувається надмірне надходження повідомлень про гостре професійне захворювання (>100% від кількості інсікованих працівників ГОЗ) в Чернігівській (захв. - 450,0 \%; смерт. 219,3\%), Дніпропетровській (смерт. - 179,6 \%), Херсонській (захв. - 260,0 \%; смерт. - 163,3 \%), Миколаївській (захв. - 123,5 \%), Черкаській (захв. - 116,7 \%), Львівській (захв. - 114,0 \%; смерт. - 141,9 \%) та Полтавській (захв. - 105,9 \%, смерт. - 117,5 \%) областях (табл. 1). Результатом спеціального експертного розслідування встановлено, що причинами зазначеного є: (1) розбіжності між адміністративною територією знаходження закладу охорони здоров'я, де працюють працівники, та місцем їх постійного проживання, де встановлено захворювання на COVID-19; (2) заниження офріційної статистичної реєстрації випадків COVID-19, як категорії «медичний працівник»; (3) невідповідності між датами офріційної реєстрації позитивного результату на SARS-CoV-2 та клінічного встановлення захворювання (смерті) на COVID-19 та інші.

При цьому найбільш важливим є приховування випадків гострого професійного захворювання на COVID-19. Найгірша ситуація спостерігається в Луганській (захв. - 4,8 \%), Івано-Франківській (захв. - 14,9\%; смер. - 47,1 \%), Рівненській (захв. - 26,1\%), Одеській (захв. - 27,4 \%; смерт. - 36,4 \%), Чернівецькій (захв. 32,2 \%), Вінницькій (захв. - 35,9 \%), Волинській (захв. - 37,3 \%), Сумській (захв. - 37,9 \%), Київській (захв. 39,3\%), Запорізькій (захв. - 43,2 \%), Хмельницькій (захв. - 43,6 \%), Донецькій (захв. - 47,8 \%) областях (табл. 1).

За перший рік епідемії SARS-CoV-2/COVID-19 було завершено 17192 комісійних розслідування з приводу підозри на гостре професійне захворювання серед працівників ГО3, 39,9 (11,6 - 92,6) \% від усіх випадків надходження повідомлення до Держпраці України. Висока частка завершених комісійних експертиз спостерігається лише в Івано-Франківській області (92,6 \%), в інших областях України вона ледве досягає відмітки 60-70 \%. Найгірша ситуація склалася в: Запорізькій обл. (11,6 \%), м. Києві (13,6 \%), Кіровоградській (15,7\%), Закарпатській (16,8 \%), Миколаївській (22,1 \%), Херсонській (30,7 \%), Чернігівській (32,6\%), Одеській (34,8\%), Черкаській $(36,2$ \%) областях (табл. 2). Результатами спеціальної експертної оцінки зазначене зумовлено: (1) відсутністю достатньої кількості лікарів-епідеміологів для здійснення епідеміологічного розслідування кожного випадку захворювання; (2) відсутністю лікарів-профрпатологів для отримання консультативного висновку щодо зв'язку захворювання з умовами праці; (3) тривалим захворюванням працівників ГОЗ, що відтермінує початок розслідування тощо.

У всіх закінчених випадках розслідування, встановлення гострого професійного захворювання COVID-19 становить $26,0(1,9-86,5) \%$. Найчастіше зв'язок захворювання на COVID-19 з умовами праці встановлюється працівникам ГОЗ в Івано-Франківській області $(86,5$ \%), у більшості інших областей України вона коливається на рівні 25-65 \%. Найнижчі показники встановлення гострого професійного захворювання реєструються в Полтавській (1,9%), Сумській (7,1%), Тернопільській (11,7 \%), Дніпропетровській (11,9\%), Миколаївській (12,6\%), Львівській (12,7\%), Донецькій $(14,1 \%)$, Закарпатській (15,3\%), Житомирській $(19,0 \%)$, Волинській (20,7 \%), Вінницькій (22,4\%), Луганській (23,5 \%) областях (табл. 2).

У випадку смерті працівника ГОЗ внаслідок COVID-19 було завершено 359 спеціальних комісійних розслідувань - 68,8 (33,3 - 100,0) \% від всіх випадків надходження повідомлення до Держпраці України. 
Кількість випадків захворювання та повідомлень про гостре професійне захворювання працівників галузі охорони здоров'я (дані Держпраці України, 12.03.2021р.)

\begin{tabular}{|c|c|c|c|c|c|c|}
\hline \multirow[b]{2}{*}{$\begin{array}{l}\text { Назва території } \\
\text { (область) }\end{array}$} & \multicolumn{3}{|c|}{$\begin{array}{c}\text { Інфріковано SARS-CoV-2I } \\
\text { захворіло на COVID-19 }\end{array}$} & \multicolumn{3}{|c|}{ Смерть від COVID-19 } \\
\hline & $\begin{array}{l}\text { Всього } \\
\text { випадків }\end{array}$ & $\begin{array}{c}\text { Кількість випадків, } \\
\text { стосовно яких } \\
\text { надійшли } \\
\text { повідомлення до Ту } \\
\text { Держпраці } \\
\end{array}$ & $\%$ & $\begin{array}{l}\text { Всього } \\
\text { випадків }\end{array}$ & $\begin{array}{c}\text { Кількість випадків, } \\
\text { стосовно яких } \\
\text { надійшли } \\
\text { повідомлення до ту } \\
\text { Держпраці } \\
\end{array}$ & $\%$ \\
\hline Всього & 67879 & 43130 & 63,5 & 610 & 522 & 85,6 \\
\hline Вінницька & 3110 & 1116 & 35,9 & 16 & 14 & 87,5 \\
\hline Волинська & 2871 & 1072 & 37,3 & 21 & 17 & 81,0 \\
\hline Дніпропетровська & 1876 & 3370 & 179,6 & 37 & 34 & 91,9 \\
\hline Донецька & 2076 & 993 & 47,8 & 34 & 20 & 58,8 \\
\hline Житомирська & 2387 & 2155 & 90,3 & 18 & 18 & 100,0 \\
\hline Закарпатська & 3058 & 2408 & 78,7 & 24 & 22 & 91,7 \\
\hline Запорізька & 4199 & 1814 & 43,2 & 24 & 22 & 91,7 \\
\hline Івано-Франківська & 2796 & 417 & 14,9 & 34 & 16 & 47,1 \\
\hline Київ (м.) & 6338 & 4647 & 73,3 & 38 & 32 & 84,2 \\
\hline Київська & 5143 & 2023 & 39,3 & 49 & 32 & 65,3 \\
\hline Кіровоградська & 1024 & 862 & 84,2 & 18 & 14 & 77,8 \\
\hline Луганська & 1113 & 53 & 4,8 & 11 & 10 & 90,9 \\
\hline Львівська & 3433 & 4871 & 141,9 & 50 & 57 & 114,0 \\
\hline Миколаївська & 1670 & 1618 & 96,9 & 17 & 21 & 123,5 \\
\hline Одеська & 3039 & 833 & 27,4 & 33 & 12 & 36,4 \\
\hline Полтавська & 1735 & 2038 & 117,5 & 17 & 18 & 105,9 \\
\hline Рівненська & 2988 & 781 & 26,1 & 9 & 9 & 100,0 \\
\hline Сумська & 2646 & 1004 & 37,9 & 14 & 9 & 64,3 \\
\hline Тернопільська & 3200 & 2136 & 66,8 & 18 & 18 & 100,0 \\
\hline Харківська & 1605 & 867 & 54,0 & 49 & 35 & 71,4 \\
\hline Херсонська & 447 & 730 & 163,3 & 5 & 13 & 260,0 \\
\hline Хмельницька & 3722 & 1622 & 43,6 & 19 & 17 & 89,5 \\
\hline Черкаська & 3622 & 2621 & 72,4 & 18 & 21 & 116,7 \\
\hline Чернівецька & 2786 & 897 & 32,2 & 33 & 23 & 69,7 \\
\hline Чернігівська & 995 & 2182 & 219,3 & 4 & 18 & 450,0 \\
\hline
\end{tabular}

Висока частка завершених спеціальних комісійних експертиз випадків смерті спостерігається в Київській (90,6 \%), Львівській (93,0 \%), Полтавській (94,4 \%) та Сумській (100,0 \%) областях. Найгірша ситуація спостерігається в Тернопільській (33,3 \%), Херсонській (38,5 \%), Миколаївській (42,9\%), Житомирській $(44,4 \%)$, Чернігівській (44,4 \%) областях (табл. 3).
У всіх закінчених випадках спеціального комісійного розслідування встановлення смерті внаслідок гострого профресійного захворювання COVID-19 становить 31,2 $(0,0-88,9)$ \%. Найчастіше зв'язок смерті внаслідок захворювання на COVID-19 з умовами праці встановлюється працівникам ГОЗ у Вінницькій (70,0 \%) та Одеській $(88,9$ \%) областях. Жодного випадку смерті внаслідок 
Показники розслідування випадків гострого професійного захворювання COVID-19 серед працівників галузі охорони здоров'я (дані Держпраці України, 12.03.2021 р.)

\begin{tabular}{|c|c|c|c|c|c|}
\hline \multirow{2}{*}{$\begin{array}{c}\text { Назва території } \\
\text { (область) }\end{array}$} & \multirow{2}{*}{$\begin{array}{c}\text { Кількість випадків, стосов- } \\
\text { но яких надійшли повідом- } \\
\text { лення до Держпраці }\end{array}$} & \multicolumn{2}{|c|}{$\begin{array}{c}\text { Кількість завершених } \\
\text { розслідувань }\end{array}$} & \multicolumn{2}{|c|}{$\begin{array}{l}\text { Встановлено гостре профре- } \\
\text { сійне захворювання COVID-19 }\end{array}$} \\
\hline & & абс. к-ть & $\%$ & абс. к-ть & $\%$ \\
\hline Всього & 43130 & 17192 & 39,9 & 4476 & 26,0 \\
\hline Вінницька & 1116 & 455 & 40,8 & 102 & 22,4 \\
\hline Волинська & 1072 & 716 & 66,8 & 148 & 20,7 \\
\hline Дніпропетровська & 3370 & 1468 & 43,6 & 174 & 11,9 \\
\hline Донецька & 993 & 610 & 61,4 & 86 & 14,1 \\
\hline Житомирська & 2155 & 886 & 41,1 & 168 & 19,0 \\
\hline Закарпатська & 2408 & 405 & 16,8 & 62 & 15,3 \\
\hline Запорізька & 1814 & 211 & 11,6 & 74 & 35,1 \\
\hline Івано-Франківська & 417 & 386 & 92,6 & 334 & 86,5 \\
\hline Київ & 4647 & 630 & 13,6 & 295 & 46,8 \\
\hline Київська & 2023 & 1002 & 49,5 & 438 & 43,7 \\
\hline Кіровоградська & 862 & 135 & 15,7 & 61 & 45,2 \\
\hline Луганська & 53 & 34 & 64,2 & 8 & 23,5 \\
\hline Львівська & 4871 & 2531 & 52,0 & 321 & 12,7 \\
\hline Миколаївська & 1618 & 357 & 22,1 & 45 & 12,6 \\
\hline Одеська & 833 & 290 & 34,8 & 159 & 54,8 \\
\hline Полтавська & 2038 & 825 & 40,5 & 16 & 1,9 \\
\hline Рівненська & 781 & 343 & 43,9 & 169 & 49,3 \\
\hline Сумська & 1004 & 448 & 44,6 & 32 & 7,1 \\
\hline Тернопільська & 2136 & 1414 & 66,2 & 165 & 11,7 \\
\hline Харківська & 867 & 529 & 61,0 & 346 & 65,4 \\
\hline Херсонська & 730 & 224 & 30,7 & 95 & 42,4 \\
\hline Хмельницька & 1622 & 1088 & 67,1 & 415 & 38,1 \\
\hline Черкаська & 2621 & 949 & 36,2 & 303 & 31,9 \\
\hline Чернівецька & 897 & 545 & 60,8 & 281 & 51,6 \\
\hline Чернігівська & 2182 & 711 & 32,6 & 179 & 25,2 \\
\hline
\end{tabular}

гострого професійного захворювання COVID-19 не визначено в Кіровоградській обл. (3 14 повідомлень, при закінченні 7 розслідувань) та в Рівненській обл. (з 9 повідомлень, при закінченні 7 розслідувань). Також найнижчі показники встановлення смерті від гострого професійного захворювання COVID-19 реєструються в Харківській (5,3 \%), Полтавській (5,9\%), Луганській (14,3 \%), Донецькій (16,7 \%), Дніпропетровській (17,4 \%) областях (табл. 3).

За результатами проведених розслідувань визначено, що причинами виникнення серед працівників ГОЗ гострого професійного захворювання COVID-19 є:
1. Інші причини (46,3 \%), в т.ч. надання медичної допомоги хворим на COVID-19 з проведенням інтервенційних процедур з високим ризиком інорікування SARS-CoV-2 (інтубація трахеї, забір бронхо-альвеолярного лаважу, здійснення штучної вентиляції легень, розтин померлих від COVID-19, лабораторні дослідження біологічних матеріалів від хворих на COVID-19 тощо) (100,0\%).

2. Організаційні причини (в забезпеченні всіх рівнів інфекційного контролю в 303) (33,7 \%), в т. ч.: невикористання засобів індивідуального захисту, за їх наявності (33,6 \%), незабезпеченість засобами індивіду- 
Таблиця 3

Показники розслідування випадків смертей внаслідок гострого професійного захворювання COVID-19 серед працівників галузі охорони здоров'я (дані Держпраці України, 12.03.2021р.)

\begin{tabular}{|c|c|c|c|c|c|}
\hline \multirow[t]{2}{*}{$\begin{array}{l}\text { Назва території } \\
\text { (область) }\end{array}$} & \multirow{2}{*}{$\begin{array}{c}\text { Кількість випадків, стосов- } \\
\text { но яких надійшли повідом- } \\
\text { лення до Держпраці }\end{array}$} & \multicolumn{2}{|c|}{$\begin{array}{c}\text { Кількість завершених } \\
\text { розслідувань }\end{array}$} & \multicolumn{2}{|c|}{$\begin{array}{c}\text { Встановлено смерть внаслідок } \\
\text { гострого професійного захво- } \\
\text { рювання COVID-19 }\end{array}$} \\
\hline & & абс. к-ть & $\%$ & абс. к-ть & $\%$ \\
\hline Всього & 522 & 359 & 68,8 & 112 & 31,2 \\
\hline Вінницька & 14 & 10 & 71,4 & 7 & 70,0 \\
\hline Волинська & 17 & 13 & 76,5 & 3 & 23,1 \\
\hline Дніпропетровська & 34 & 23 & 67,6 & 4 & 17,4 \\
\hline Донецька & 20 & 12 & 60,0 & 2 & 16,7 \\
\hline Житомирська & 18 & 8 & 44,4 & 2 & 25,0 \\
\hline Закарпатська & 22 & 15 & 68,2 & 7 & 46,7 \\
\hline Запорізька & 22 & 12 & 54,5 & 3 & 25,0 \\
\hline Івано-Франківська & 16 & 11 & 68,8 & 6 & 54,5 \\
\hline Київ & 32 & 23 & 71,9 & 8 & 34,8 \\
\hline Київська & 32 & 29 & 90,6 & 13 & 44,8 \\
\hline Кіровоградська & 14 & 7 & 50,0 & 0 & 0,0 \\
\hline Луганська & 10 & 7 & 70,0 & 1 & 14,3 \\
\hline Львівська & 57 & 53 & 93,0 & 15 & 28,3 \\
\hline Миколаївська & 21 & 9 & 42,9 & 4 & 44,4 \\
\hline Одеська & 12 & 9 & 75,0 & 8 & 88,9 \\
\hline Полтавська & 18 & 17 & 94,4 & 1 & 5,9 \\
\hline Рівненська & 9 & 7 & 77,8 & 0 & 0,0 \\
\hline Сумська & 9 & 9 & 100,0 & 3 & 33,3 \\
\hline Тернопільська & 18 & 6 & 33,3 & 2 & 33,3 \\
\hline Харківська & 35 & 19 & 54,3 & 1 & 5,3 \\
\hline Херсонська & 13 & 5 & 38,5 & 1 & 20,0 \\
\hline Хмельницька & 17 & 14 & 82,4 & 7 & 50,0 \\
\hline Черкаська & 21 & 15 & 71,4 & 5 & 33,3 \\
\hline Чернівецька & 23 & 18 & 78,3 & 7 & 38,9 \\
\hline Чернігівська & 18 & 8 & 44,4 & 2 & 25,0 \\
\hline
\end{tabular}

ального захисту (10,5 \%), порушення санітарно-епідеміологічного режиму в 303 (8,3 \%), виконання робіт 3 відключеними або несправними засобами колективного захисту системами сигналізації вентиляції, освітлення чи їх відсутність тощо (3,6 \%), відсутність або неякісне проведення інструктажу з охорони праці (3,2 \%), недосконалість інструкцій з охорони праці або їх відсутність (1,9\%), незастосування засобів колективного захисту, у разі їх наявності $(0,4 \%)$ та інші $(38,5 \%)$. До організаційних причин виникнення COVID-19 можна також віднести: незабезпеченість засобами індивідуального за- хисту; виконання робіт з відбору біологічного матеріалу без захисних окулярів або щитка для обличчя та ізоляційного (захисного) халата; недоліки під час навчання безпечного проведення робіт - допуск працівника до виконання нової для нього роботи (відбір біологічного матеріалу) без проходження навчання, перевірки знань і первинного інструктажу з питань охорони праці; невиконання вимог інструкцій з охорони праці тощо.

3. Психофрізіологічні причини (14,0\%), в т. ч. робота в екстремальних умовах надання стаціонарної допомоги хворим на COVID-19 («червона зона»), що викли- 
кають втому на робочому місці та зниження пильності працівників ГОЗ.

4. Технічні причини (4,5 \%), в т. ч.: невідповідність засобів колективного та індивідуального захисту встановленим вимогам та їх недостатність (в т. ч. невідповідність 303 вимогам для прийому інфекційних хворих 3 діагнозом COVID-19 (78,3 \%), інші $(21,7 \%)$.
5. Техногенні, природні, екологічні та соціальні причини (1,4\%), в т. ч.: несвоєчасне виявлення та ізоляція джерела збудника інфекції, висока концентрація SARS-CoV-2 в інфекційних відділеннях 303, викид небезпечних біологічних речовин тощо (100,0%) (табл. 4).

Таблиця 4

Розподіл кількості потерпілих від нещасних випадків, за даними актів Н-1/П, пов'язаних з виробництвом за найбільш травмонебезпечними причинами настання гострих профресійних захворювань COVID-19 за 2020 р.

\begin{tabular}{|c|c|c|c|c|c|}
\hline \multirow{2}{*}{$\begin{array}{l}\text { № } \\
\text { 3/ח }\end{array}$} & \multirow{2}{*}{$\begin{array}{c}\text { Причина настання нещасного } \\
\text { випадку }\end{array}$} & \multicolumn{2}{|c|}{ Кількість складених актів } & \multicolumn{2}{|c|}{ У відсотках до загальної кількості } \\
\hline & & всього & $\begin{array}{c}\text { В т. ч. } \\
\text { смертельно }\end{array}$ & всього & $\begin{array}{c}\text { В т.ч. } \\
\text { смертельно }\end{array}$ \\
\hline \multicolumn{2}{|c|}{ Всього по Україні } & 3054 & 66 & 100,0 & 2,2 \\
\hline \multicolumn{2}{|c|}{ 1. Організаційні причини } & 1030 & 30 & 33,7 & 1,0 \\
\hline \multicolumn{6}{|c|}{ В тому числі: } \\
\hline 1.1 & Інші організаційні причини & 393 & 5 & 12,9 & 0,2 \\
\hline 1.2 & $\begin{array}{l}\text { Невиконання вимог інструкцій з охо- } \\
\text { рони праці }\end{array}$ & 324 & 6 & 10,6 & 0,2 \\
\hline 1.3 & $\begin{array}{l}\text { Невикористання засобів індивіду- } \\
\text { ального захисту за їх наявності }\end{array}$ & 155 & 10 & 5,1 & 0,3 \\
\hline 1.4 & $\begin{array}{l}\text { Незабезпеченість засобами індиві- } \\
\text { дуального захисту }\end{array}$ & 64 & 8 & 2,1 & 0,3 \\
\hline \multicolumn{2}{|c|}{ 2. Психофрізіологічні причини } & 429 & 11 & 14,1 & 0,4 \\
\hline \multicolumn{6}{|c|}{ В тому числі: } \\
\hline 2.1 & Інші психофрізіологічні причини & 288 & 2 & 9,4 & 0,1 \\
\hline \multicolumn{2}{|c|}{ 3. Технічні причини } & 138 & 4 & 4,5 & 0,1 \\
\hline \multicolumn{6}{|c|}{ В тому числі: } \\
\hline 3.1 & $\begin{array}{l}\text { Невідповідність засобів колективно- } \\
\text { го та індивідуального захисту вста- } \\
\text { новленим вимогам та їх недостат- } \\
\text { ність }\end{array}$ & 108 & 0 & 3,5 & 0,0 \\
\hline \multicolumn{2}{|c|}{$\begin{array}{l}\text { 4. Техногенні, природні, екологічні та } \\
\text { соціальні причини }\end{array}$} & 43 & 1 & 1,4 & 0,03 \\
\hline \multicolumn{6}{|c|}{ В тому числі: } \\
\hline 4.1 & $\begin{array}{l}\text { Викид небезпечних хімічних, радіо- } \\
\text { активних, біологічних речовин }\end{array}$ & 43 & 1 & 1,4 & 0,03 \\
\hline \multicolumn{2}{|c|}{ 5. Інші причини } & 1414 & 20 & 46,3 & 0,7 \\
\hline
\end{tabular}

\section{Висновки}

1. Кількість хворих на гостре професійне захворювання COVID-19 постійно збільшується, має хвилеподібний характер, відповідно до загального перебігу епідемії в популяції населення України. Кумулятивний ризик інфрікування SARS-CoV-2 працівниками галузі охорони здоров'я вищий в 2,5 рази, ніж серед загального населення, а смерті від COVID-19 - в 1,1 разу.
2. Домінуючі причини інфрікування SARS-CoV-2 працівників галузі охорони здоров'я: надання медичної допомоги хворим на COVID-19 зі здійсненням інтервенційних процедур (46,3 \%); наявні організаційні недоліки в забезпеченні інфрекційного контролю в 303 (33,7 \%); психофрізіологічні причини, які обумовлені роботою працівників в екстремальних умовах надання стаціонарної допомоги хворим на COVID-19 («червона зона») 


\section{ОРИГІНАЛЬНІ ДОСЛІДЖЕННЯ}

(14,0 \%); технічні (4,5\%); техногенні, природні, екологічні та соціальні $(1,4 \%)$.

3. Нормативне регулювання встановлення гострого профресійного захворювання на COVID-19 регламентовано тільки для працівників галузі охорони здоров'я і потребує розповсюдження його й на інші види економічної діяльності в Україні (працівники освіти, соціальної допомоги тощо).

4. $Є$ суттєві організаційні та ресурсні (кадрові) недоліки: з надання повідомлень до Держпраці України щодо підозри гострого професійного захворювання на COVID-19 та смерті від нього; щодо об'єктивної статистичної реєстрації випадків захворювання працівників галузі охорони здоров'я на COVID-19; щодо своєчасного та повного розслідування зв'язку захворювання (смерті) з умовами праці тощо.

5. Подальші дослідження будуть спрямовані на удосконалення системи оцінки ризиків та убезпечення роботи працівників галузі охорони здоров'я, в умовах епідемії SARS-CoV-2/COVID-19 в Україні.

\section{Література}

1. Parry J. Pneumonia in China: lack of information raises concerns among Hong Kong health workers / J. Parry // BMJ. - 2020. - Vol. 368. DOI:10.1136/bmj.m56.

2. COVID-19 pandemic // Wikipedia. - 2021. URL : https://cutt. ly/nxgsQhR.

3. Naming the coronavirus disease (COVID-19) and the virus that causes it / WHO Country \& Technical Guidance - Coronavirus disease (COVID-19). - 2020. URL : https://cutt.ly/zxgeQa2.

4. WHO Director-General's opening remarks at the media briefing on COVID-19 / WHO. - 11 March 2020. URL : https://cutt.ly/Rxggg3W.

5. (2020). International Statistical Classification of Diseases and Related Health Problems 10th Revision / WHO. - 2020. URL: https:// cutt.ly/bxgiUM3.

\section{References}

1. Parry, J. (2020). "Pneumonia in China: lack of information raises concerns among Hong Kong health workers", BMJ., 368. DOI:10.1136/ bmj.m56.

2. Wikipedia. (2021). COVID-19 pandemic. Retrieved from: https:// cutt.ly/nxgsQhR.

3. (2020). Naming the coronavirus disease (COVID-19) and the virus that causes it. WHO Country \& Technical Guidance - Coronavirus disease (COVID-19). Retrieved from: https://cutt.ly/zxgeQa2.

4. (2020). WHO Director-General's opening remarks at the media briefing on COVID-19 - 11 March. 2020. WHO. Retrieved from: https:// cutt.ly/Rxggg3W.

5. (2020). International Statistical Classification of Diseases and Related Health Problems 10th Revision. WHO. Retrieved from: https:/l cutt.ly/bxgiUM3.

6. Международные методические рекомендации по удостоверению и кодированию COVID-19 в качестве причины смерти. Основаны на международной статистической классификации болезней и проблем, связанных со здоровьем (МКБ) / ВОЗ. - 20 апреля 2020. URL: https://cutt.ly/Xxgjxdk.

7. WHO (2021). WHO Coronavirus (COVID-19) Dashboard / WHO. - 2021. URL : https://covid19.who.int.

8. Оперативний моніторинг ситуації довкола COVID-19 / Haціональна служба здоров'я України. - 2021. URL: https://cutt.ly/ DxgzRMY.

9. Кризис COVID-19 и сектор здравоохранения / МОT. - 2020. URL: https://cutt.ly/ojUFNDY

10. Нормы MOT и COVID-19 (коронавирус) / MOT. - 2020. URL: https://cutt.ly/fjUGdAf

6. (2020). International guidelines for the identification and coding of COVID-19 as a cause of death. Based on the International Statistical Classification of Diseases and Related Health Problems (ICD) on April 20, 2020. WHO. Retrieved from: https://cutt.ly/Xxgjxdk.

7. (2021). WHO Coronavirus (COVID-19) Dashboard. WHO. Retrieved from: https://covid19.who.int.

8. (2021). National Health Service of Ukraine. Operational monitoring of the situation around COVID-19. Retrieved from: https:// cutt.ly/DxgzRMY.

9. (2020). COVID-19 crisis and the health sector. ILO. Retrieved from: https://cutt.ly/ojUFNDY.

10. (2020). ILO standards and COVID-19 (Coronavirus). ILO. Retrieved from: https://cutt.ly/fjUGdAf. 


\section{ORGANIZATION OF INVESTIGATION AND MEDICAL AND STATISTICAL PATTERN OF ACUTE OCCUPATIONAL DISEASE COVID-19 IN WORKERS OF THE HEALTHCARE SYSTEM OF UKRAINE (FIRST YEAR OF THE PANDEMIC: 2020- 2021)}

A.M. Nahorna ${ }^{1}$, D.V. Varyvonchyk ${ }^{2}$, L.V. Kharchuk ${ }^{3}$, N.V. Medvedovska ${ }^{4}$, I.H. Kononova ${ }^{5}$, V.A. Hvozdetsky ${ }^{6}$

${ }^{1}$ The National Academy of Medical Sciences of Ukraine

${ }^{2}$ P.L. Shupyk National University of Health of Ukraine

${ }^{3}$ State Labor Service of Ukraine

${ }^{4}$ Scientific Coordination Department of the National Academy of Medical Sciences of Ukraine

${ }^{5}$ L.V. Hromashevskyi Institute of Epidemiology and Infectious Diseases of the National Academy of Medical Sciences of Ukraine

${ }^{6}$ Kundiyev Institute of Occupational Health of the National Academy of Medical Sciences of Ukraine

SUMMARY. In 2020, the problem of human coronavirus infection (2019-nCoV/SARS-CoV-2) became relevant worldwide. On March 11, 2020, the WHO declared a pandemic of SARS-CoV-2. In one year of the pandemic in the world (as of March 12, 2021) 120.1 million cases of SARS-CoV-2 infection were registered, of which 2.7 million people died because of COVID-19.

In Ukraine, 1.451 million people were infected with SARS-CoV-2 (including 68.3 thousand health care workers (HCW)); of whom 28.1 thousand people died because of COVID-19 (including HCW - 612 persons). Today one of the most important scientific and practical problems is risk assessment and prevention of this acute occupational pathology.

Patients and methods. The official statistical data of the Ministry of Health of Ukraine on the normative regulation of the epidemic investigation of COVID-19, on organization of the investigation of COVID-19 in the field of health care, labor protection, registration of cases of COVID-19 were used.

Statistical data on the morbidity of COVID-19 (according to the territorial divisions of the Social Insurance Fund of Ukraine, State Labor Service of Ukraine) for 2020 March 2021 were obtained and analyzed. Common statistical research methods were used to characterize the data taken from a continuous sample in Ukraine.

Results and discussion. The normative-legal acts on the procedure of investigation of cases of acute occupational disease of COVID-19 were analyzed, namely the Order of the Ministry of Health of Ukraine of February 25, 2020 No 521 "On amendments in the List of especially dangerous, dangerous infectious and parasitic human diseases and carriers of these pathogens", and also according to Instruction No 374 "On the use of the list of occupational diseases", approved by a joint Order of the Ministry of Health, the National Academy of Medical Sciences of Ukraine, the Ministry of Labor of December 29, 2000 No 374/68/33"; Order of the Ministry of Health of Ukraine dated July 15, 2020 No 1604 on the List of positions of medical and other workers directly involved in the elimination of the epidemic and implementation of measures to prevent the spread of acute respiratory disease COVID-19 caused by Coronavirus SARS-CoV-2 and treatment of patients with acute respiratory disease COVID-19 caused by Coronavirus SARS-CoV-2".

Resolution of the Cabinet of Ministers of May 13, 2020 No 394 Section V of the List of Occupational Diseases approved by the Resolution of the Cabinet of Ministers of November 08, 2000 No 1662 was supplemented by acute respiratory disease COVID-19 caused by Coronavirus SARS-CoV-2, concerning only the work of "medical and other workers" directly involved in the liquidation of the epidemic and implementation of measures to prevent the spread of acute respiratory disease COVID-19 caused by Coronavirus SARSCoV-2, and treatment of patients with acute respiratory disease COVID-19 caused by Coronavirus SARS-2. Medical and statistical regularities of SARS-COV-2 infection and morbidity of COVID-19 disease for healthcare workers were determined. The number of reports on cases of SARS-CoV-2 infection at workplace (suspicion of acute occupational disease) received by the State Labor Service of Ukraine (March 12, 2021) was 43,130 employees, including deaths from COVID-19 -522 .

In general, the completeness of acute occupational disease reports was (relative to reported cases on health care workers (HCW) infection): for SARS-CoV-2 infection/COVID-19 disease - 63.5 (4.8-219.3) \%; deaths from COVID-19 - 85.6 (36.4-450.0) \%.

Fluctuations in the incidence of COVID-19 vary significantly by region; the causes require more careful analysis, they are multifaceted, but the identified regularities can serve as a basis for taking management decisions on accounting, registration, prevention and treatment of this pathology.

Conclusion. The number of patients with acute occupational disease COVID-19 is constantly increasing, is of a wavy nature, in accordance with the general course of the epidemic in the population of Ukraine. The cumulative risk of infection from SARS-CoV-2 for health care workers is 2.5 times higher than for the general population, and the death rate from COVID-19 is 1.1 times higher. 
Dominant causes of SARS-CoV-2 infection in healthcare professionals are: provision of medical care to patients with COVID-19, with intervention procedures (46.3 \%); there are organizational shortcomings in ensuring infection control in the health care institutions $(\mathrm{HCl})$ (33.7\%); psychophysiological reasons due to the work of employees in extreme conditions of inpatient care for patients with COVID-19 ("red zone") (14.0\%); technical reasons (4.5\%); technogenic, natural, ecological and social (1.4\%).

The normative regulation in establishing an acute occupational disease of COVID-19 is regulated only for health care workers and requires its extension to other economic activities in Ukraine (workers of education, social assistance, etc.).

There are significant organizational and resource (personnel) shortcomings: on submission of notifications to the State Labor Service of Ukraine on suspicion of acute occupational disease on COVID-19 and death from it; on objective statistical registration of cases of diseases of healthcare workers on COVID-19; on timely and complete investigation of the connection between illness (death) and working conditions, etc.

Further research will be aimed at improving the system of risk assessment and provision of occupational safety of health care workers in the context of the SARS-CoV-2/ COVID-19 epidemic in Ukraine.

Key words: acute occupational disease; COVID-19, health care system; causes of SARS-CoV-2 infection.

\section{Відомості про авторів:}

Нагорна Антоніна Максимівна - д. мед. н., профресорка, членкиня-кореспондентка Національної академії медичних наук України

Варивончик Денис Віталійович - д. мед. н., профресор, Національний медичний університет охорони здоров'я імені П.Л. Шупика, завідувач кафедри медицини праці, психофрізіології та медичної екології; e-mail: dv7@ukr.net

Харчук Людмила Володимирівна - Державна служба України з питань праці; e-mail: gigienapratsi_dsp@ukr.net
Медведовська Наталія Володимирівна - д. мед. н., професорка, начальниця науково-координаційного управління НАМН України; e-mail: medvedovsky@ukr.net

Кононова Ірина Георгіївна - к. мед. н, ст. н. с., т. в. о. вченого секретаря ДУ «Інститут епідеміології та інсрекційних хвороб імені Л.В. Громашевського НАМН України»; е-mail: ntgu@ukr.net

Гвоздецький Віктор Анатолійович - к. мед. н., ст. н. с. відділу профпатології ДУ «Інститут медицини праці імені Ю.І. Кундієва Національної академії медичних наук України»; e-mail: viktorhvozdeckij431@gmail.com

\section{Information about the authors:}

Nahorna A.M. - MD, Professor, Corresponding Member of the National Academy of Medical Sciences of Ukraine; e-mail: dv7@ukr.net.

Varyvonchyk D.V. - MD, Professor, P.L. Shupyk National Medical University, Head of the Department of Occupational Health, Psychophysiology and Medical Ecology; e-mail: dv7@ ukr.net.

Kharchuk L.V. - State Labor Service of Ukraine; e-mail: ntgu@ukr.net.

Medvedovska N.V. - MD, Professor, Head of the Scientific Coordination Department of the National Academy of Medical Sciences of Ukraine; e-mail: medvedovsky@ukr.net.

Kononova I.H. - PhD, Senior scientific worker, temporaly in charge Scientific Secretary in the L.V. Hromashevskyi Institute of Epidemiology and Infectious Diseases of the National Academy of Medical Sciences of Ukraine; e-mail: ntgu@ukr. net.

Hvozdetsky V. A. - PhD, Senior scientific worker, Department of Occupational Pathology, Kundiyev Institute of Occupational Health of the NAMS of Ukraine; e-mail: viktorhvozdeckij431@gmail.com.

Конорлікт інтересів: немає.

Authors have no conflict of interest to declare.

Отримано 21.04.2021 p. 